\title{
Karyotype Analysis of Alnus Mill. (Betulaceae) Species Originating From Northeastern Asia
}

\author{
By Liu Jun ${ }^{1)}$, Ren Bao-QIng ${ }^{1)}$, Luo Peigao ${ }^{2)}$ and Ren Zhenglong ${ }^{2),}{ }^{*}$ )
}

(Received 25 $5^{\text {th }}$ May 2009)

\begin{abstract}
Alnus Mill. (alder) is an ecologically valuable tree genus. It is essential to study its genetic makeup in order to use alder trees to their full potential. Five specimens from four Alnus species (A. mandshurica, A. pendula, A. sibirica, and A. sieboldiana), found in northeastern Asia, were subjected to karyotype analysis. The analysis showed that these tree samples could be divided into three categories based on chromosome numbers or ploidy levels: viz., $2 \mathrm{n}=(4 \mathrm{x})=28,2 \mathrm{n}=(8 \mathrm{x})=56$ and $2 \mathrm{n}=(16 \mathrm{x})=112$. The differences in chromosome number and karyotype parameters among Alnus species and even within the same species possibly resulted from natural polyploidization. Comparing the chromosome numbers of Alnus species in China with those in Japan showed that there appear to be only two categories in China, whereas there are up to five categories in Japan. The earliest fossil records of Alnus pollen were also discovered in Japan. We conclude that the center origin of Alnus spp. is Japan rather than China.
\end{abstract}

Key words: alder; Asia; center of origin; chromosomal evolution; karyotype analysis; polyploidy.

\section{Introduction}

Alnus Mill. (alder) is one of the genera within the family Betulaceae. There are more than 40 named alder species that are distributed widely in Asia, Europe and America (KuANG, 1979; DAwson, 1990). They are usually deciduous trees or shrubs, and they colonize ecologically extreme or disturbed habitats. They are becoming increasingly important for their potential role in greening because they grow rapidly and can improve soil fertility and stability due to their ability to form both ectomycorrhizal (ECM) and actinorhizal relationships (BRUNNER et al., 1990).

In China, there are many extremely wet or arid areas that need to be green. Choosing the appropriate tree species and improving their adaptation to particular set of climatic conditions is a valuable and effective method of greening used in forestry. The adaptability of plants to the environment is controlled by their genetic makeup. Alder species often grow in ecologically extreme environments, such as fertile soils and hot and dry habitats, partly owing to the various numbers of chromosomes (KRSTINIĆ, 1994). Hence, it is important to estab-

1) Forestry Department, Forestry and Horticulture Institute, Sichuan Agricultural University, Yaan, Sichuan 625014, China.

2) State Key Laboratory of Plant Breeding and Genetics, Sichuan Agricultural University, Yaan, Sichuan 625014, China.

*) Corresponding author: Zhenglong Ren. Tel. 86-835-2882123, Fax 86-835-2882478. E-mail: zhlrenlab@yahoo.com.cn lish the relationship between ecological adaptability and the chromosome number of the various alder species. However, the chromosome number of many Alnus species remains to be elucidated. In this study, we analyzed the karyotypes of four Alnus species (five specimens) collected in China. In addition, their evolutionary relationships are discussed, based on the numbers and morphologies of their chromosome sets.

\section{Materials and Methods \\ Specimen collection and characterization}

In this study, five specimens, representing four species, were examined. Seeds were taken during the maturation stage at various sites in China: $A$. mandshurica (Callier) Hand.-Mazz. from Changbai Mountain, Jilin province, altitude $1.200 \mathrm{~m}$; A. pendula Matsum., originally introduced from Japan by the Forestry Bureau of Liangshan and collected on Liangshan, Sichuan, altitude 1.300 m; A. sibirica Fisch. ex Turcz., originally collected by the Forestry Bureau of Liangshan, Sichuan, altitude $1.300 \mathrm{~m}$, and collected from Tonghua, Jilin, altitude $1.200 \mathrm{~m}$; and A. sieboldiana Matsum. from the dendrology garden of Sichuan Agricultural University, altitude $700 \mathrm{~m}$.

\section{Growth and treatment of plant materials}

The root meristems of germinating seeds were pretreated in distilled water at $0{ }^{\circ} \mathrm{C}$ for $24 \mathrm{~h}$ and then fixed in ethanol:lactic acid (3:1) overnight and stored in $70 \%$ aqueous ethanol. Root tips were stained according to the traditional Feulgen technique (Ramachandran et al. 1983), and meristems were macerated in $1 \mathrm{M} \mathrm{HCl}$ at $60^{\circ} \mathrm{C}$ for $10 \mathrm{~min}$ before squashing.

\section{Chromosome observations and counts}

The chromosome number was counted from at least 30 metaphase cells, and images of each specimens were taken from more than 10 cells, including 4-6 individual cells, using a Leica-DMR light microscope fitted with a digital camera DFC320 (LEICA, Germany). Then the five clearest photographs were employed to measure the parameters of chromosomes. The terms used to describe the chromosome morphologies are those proposed by LEVAN et al. (1964), with the abbreviations (m) for metacentric chromosomes with arm ratios ranging from 1.01 to $1.69,(\mathrm{sm})$ for submetacentric chromosomes with arm ratios from 1.7 to 3 , (st) for subtelocentric chromosomes with arm ratios from 3.01 to 7 , and (t) for subterminal telocentric chromosomes with arm ratios of greater than 7 . 
Table 1. - Classification of karyotypes. RLS = ratio of the length of the largest chromosome to the length of the smallest chromosome.

\begin{tabular}{|l|l|l|l|l}
\hline \multirow{2}{*}{ RLS } & \multicolumn{4}{|l}{ Proportion of chromosomes with arm ratio > 2: 1 } \\
\cline { 2 - 5 } & 0.0 & $0.01-0.5$ & $0.51-0.99$ & 1 \\
\hline$<2: 1$ & $1 \mathrm{~A}$ & $2 \mathrm{~A}$ & $3 \mathrm{~A}$ & $4 \mathrm{~A}$ \\
\hline $2: 1-4: 1$ & $1 \mathrm{~B}$ & $2 \mathrm{~B}$ & $3 \mathrm{~B}$ & $4 \mathrm{~B}$ \\
\hline$>4: 1$ & $1 \mathrm{C}$ & $2 \mathrm{C}$ & $3 \mathrm{C}$ & $4 \mathrm{C}$ \\
\hline
\end{tabular}

\section{Data analysis}

Idiograms were drawn based on centromeric indices and were arranged in order of decreasing size and chromosome type. For numerical characterization of the karyotypes, the following parameters were documented: range of chromosome lengths, total chromosome lengths of the haploid complement (TCL), centromeric index (CI), intrachromosomal asymmetry index (A1) $\left[\sum(\mathrm{b} / \mathrm{B}) / \mathrm{n}\right]$, and interchromosomal asymmetry index (A2) $s / x$, where $b$ and $B$ designate for the mean length of short and long arms of each pair of homologues, respectively; $n$ is the number of homologues; $s$ is the standard deviation; and $x$ is the mean chromosome length. The karyotype asymmetry was described by $\mathrm{TF} \%$ (total sum of short arm length/total sum of chromosome length) (HUZIWARA, 1962). Chromosomes were classified on the basis of arm ratio according to STEBBINS (1971) (Table 1).

\section{Results}

The five specimens from four Alnus species had $2 \mathrm{n}=$ $28,2 \mathrm{n}=56$, or $2 \mathrm{n}=112$ chromosomes. Karyotype formu- lae $(\mathrm{KF})$ and parameters for the studied species are summarized in Table 2. Figure 1 illustrates the mitotic metaphases and idiograms.

A. mandshurica is mainly distributed in Heilongjiang and Jilin provinces, and the seeds used for karyotype analysis came from Changbaishan in Jilin. The karyotype formula was $\mathrm{K}(2 \mathrm{n})=28=24 \mathrm{~m}+4 \mathrm{sm}$, and the arm ratio was 2.138 . Chromosomes with an arm ratio greater than 2 made up only $7.14 \%$ of total number of chromosomes. The karyotype of $A$. mandshurica was classified as 2B, with an arm index of 56 and a karyotype dissymmetry coefficient of 57.554. In the karyotype, the longest and the shortest pairs of the complement were both $\mathrm{m}$.

A. pendula originated from Japan. Its karyotype formula was $\mathrm{K}(2 \mathrm{n})=28=6 \mathrm{~m}+20 \mathrm{sm}+2 \mathrm{st}$, and its arm ratio was 2.04. Chromosomes with an arm ratio greater than 2 made up $35.7 \%$ of the chromosomes; that is, A. pendula is type $2 \mathrm{~B}$. The arm index was 54 , and the karyotype dissymmetry coefficient was 65.632. The longest chromosome pairs were sm, and the shortest were $\mathrm{m}$.

A. sibirica originated in Heilongjiang, Jilin, Liaolin, Shandong, Korea, Japan and the former USSR. Its karyotype formula was $\mathrm{K}(2 \mathrm{n})=56=52 \mathrm{~m}+4 \mathrm{sm}$, and its arm ratio was 2.353. Chromosomes with an arm ratio greater than 2 accounted for only $7.14 \%$ of all chromosomes. Its karyotype was $2 \mathrm{~B}$, its arm index was 54 , and its karyotype dissymmetry coefficient was 58.754 . Unlike the karyotype of $A$. pendula, the longest chromosome pairs were $m$, whereas the shortest was sm. Seeds from a sample of $A$. sibirica obtained by the Biology Department of Jilin Tonghua Normal University showed a different result. Its karyotype formula was $(2 \mathrm{n})=28=$ $22 \mathrm{~m}+4 \mathrm{sm}+2 \mathrm{st}$, and its arm ratio was 1.913 . Chro-

Table 2. - Comparative karyotypes of five specimens from four Alnus species. $\mathrm{KF}=$ karyotype formulae, TCL $=$ total chromosome lengths of the haploid complement, A1 = intrachromosomal asymmetry index, $\mathrm{A} 2$ = interchromosomal asymmetry index, $\mathrm{CI}=$ mean centromeric index, $\mathrm{SE}=$ standard error, $\mathrm{RLS}=$ ratio of the length of the largest chromosome to the length of the smallest chromosome, CK = classification of karyotype, $\mathrm{TF} \%$ = total sum of short arm length/total sum of chromosome length.

\begin{tabular}{|c|c|c|c|c|c|c|c|c|c|}
\hline Species & $\mathrm{KF}$ & RLS & CK & $\mathrm{TCL}+\mathrm{SE}$ & Range & $\mathrm{A}_{1}$ & $\mathrm{~A}_{2}$ & $\mathrm{TF} \%$ & $\mathrm{CI}+\mathrm{SE}$ \\
\hline $\begin{array}{l}\text { A. mandshurica } \\
(2 \mathrm{n}=28)\end{array}$ & $24 m+4 s m$ & 2.138 & $2 \mathrm{~B}$ & $\begin{array}{l}99.998 \pm 1 . \\
569\end{array}$ & $\begin{array}{l}5.216 \\
11.151\end{array}$ & 0.238 & 0.220 & 42.4 & $\begin{array}{r}42.843 \\
\pm 5.153\end{array}$ \\
\hline $\begin{array}{l}\text { A. pendula } \\
(2 \mathrm{n}=28)\end{array}$ & $\begin{array}{l}6 \mathrm{~m}+20 \mathrm{sm}+ \\
2 \mathrm{st}\end{array}$ & 2.04 & $2 \mathrm{~B}$ & $\begin{array}{l}100.001 \pm \\
1.566\end{array}$ & $\begin{array}{l}5.543 \\
11.308\end{array}$ & 0.450 & 0.219 & 34.4 & $\begin{array}{l}34.752 \\
\pm 7.04\end{array}$ \\
\hline $\begin{array}{l}\text { A. } \quad \text { sibirica } \\
(2 \mathrm{n}=28)\end{array}$ & $\begin{array}{l}22 \mathrm{~m}+4 \mathrm{sm}+2 \\
\text { st }\end{array}$ & 1.913 & $2 \mathrm{~A}$ & $\begin{array}{l}100.0 \pm 1.4 \\
83\end{array}$ & $\begin{array}{l}4.25 \\
10\end{array}$ & 0.281 & 0.208 & 41.2 & $\begin{array}{l}41.051 \\
\pm 7.258\end{array}$ \\
\hline $\begin{array}{l}\text { A. } \quad \text { sibirica } \\
(2 n=56)\end{array}$ & $52 \mathrm{~m}+4 \mathrm{sm}$ & 2.353 & $2 \mathrm{~B}$ & $\begin{array}{l}100.001 \pm \\
0.594\end{array}$ & $\begin{array}{l}2.861 \\
5.473\end{array}$ & 0.216 & 0.166 & 43.5 & $\begin{array}{l}43.636 \\
\pm 4.436\end{array}$ \\
\hline $\begin{array}{l}\text { A. sieboldiana } \\
(2 \mathrm{n}=112)\end{array}$ & $\begin{array}{l}82 \mathrm{~m}+26 \mathrm{sm}+ \\
4 \mathrm{st}\end{array}$ & 2.577 & $2 \mathrm{~B}$ & $\begin{array}{l}100.0 \pm \\
0.276\end{array}$ & $\begin{array}{l}1.04 \\
2.68\end{array}$ & 0.301 & 0.155 & 40.7 & $\begin{array}{l}40.594 \\
\pm 6.392\end{array}$ \\
\hline
\end{tabular}




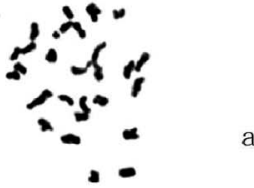

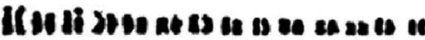

$+1$

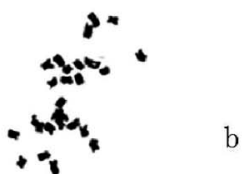

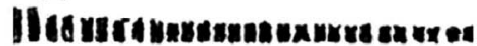

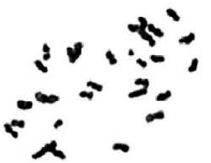

$\mathrm{C}$

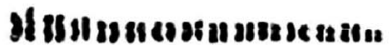

Figure 1. - Somatic chromosomes of collected Alnus species. a, A. mandshurica

b, A. pendula; c, A. sibirica $(2 \mathrm{n}=28) ; \mathrm{d}$, A. sibirica $(2 \mathrm{n}=56) ; \mathrm{e}$, A. sieboldiana .

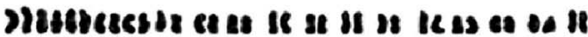

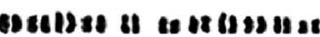

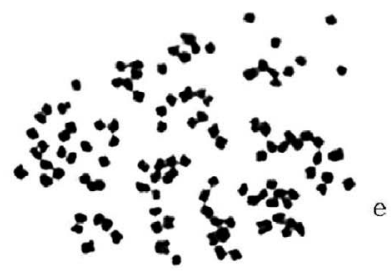

배

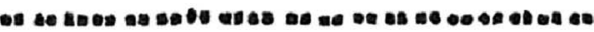

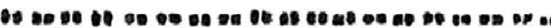

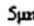

mosomes with arm ratios greater than 2 represented $3.57 \%$ of chromosomes. Its karyotype was $2 \mathrm{~A}$, its arm index was 112 , and its karyotype dissymmetry coefficient was 56.468. Both the longest and shortest chromosome pairs were $\mathrm{m}$.

A. sieboldiana originated in Japan. Its karyotype formula was $\mathrm{K}(2 \mathrm{n})=112=82 \mathrm{~m}+26 \mathrm{sm}+4 \mathrm{st}$, and its arm ratio was 2.577. Chromosome with an arm ratio greater than 2 made up $8.93 \%$ of all chromosomes. Its karyotype was type $2 \mathrm{~B}$, its arm index was 224 , and its karyotype dissymmetry coefficient was 59.415. The longest and shortest chromosome pairs were $\mathrm{m}$.

\section{Discussion}

Species of the genus Alnus are mostly located in the Northern Hemisphere. Generally, alders show great variability in their morphological and physiological properties. At present, alders are attracting increasing attention as forest trees because of their multiple uses in both the forestry and wood industries. They are fast growing and ameliorative species, with the ability to fix atmospheric nitrogen. Alders can be used in short rotation (cycles) special-purpose plantations because of their rapid biomass production (KRSTINIĆ, 1994). As mentioned above, there is a need to document the existing genetic diversity in terms of chromosome numbers and karyotype compositions (MANDAKOVA and LYSAK, 2008). The four species studied here were classified into three chromosome types, with $2 \mathrm{n}=28,56$ or 112 (Table 2). Based on the parameters given in Table 2 , the three species with $2 \mathrm{n}=28$ were clearly different. The two specimens of $A$. sibirica had different chromosome numbers and likely represented two different species rather than one species.

Karyotypes contain information such as the number, size, banding patterns, and centromere positions of a chromosome complement. Variations in these characteristics often reflect to the evolution of the species (WATANABE et al., 1995, 1999; SHAN et al., 2003; LIU et al., 2006). The primary chromosome number of Alnus is now commonly accepted as $\mathrm{x}=14$, as suggested by FuRLOw (1979), although CHIBA (1962) earlier documented $\mathrm{x}=7$. Studies by various authors found four different chromosome numbers in Alnus, including 2n = 14, 28, 42 and 56 (Murai, 1964; Somego, 1976; Probatova and SokolOVSKAYA, 1989; RESTREPO, 1994; STARODUBTSEV, 1997; CHEN and LI, 2004; REN and LIU, 2006). In this study, there were three chromosome numbers; viz., $2 \mathrm{n}=28,56$, and 112. Combining the present data with previous results suggests that the basic chromosome number of Alnus is $\mathrm{x}=7$ and that $A$. sieboldiana represents a new chromosome type. This provides further evidence that Alnus is one of the few polyploidized woody plant genera. Given that the basic chromosome number is $\mathrm{x}=7$, the ploidy levels are 4, 8, and 16 .

Based on the of karyotype information from this study, there are two evolutionary processes in occurring Alnus: asymmetry and polyploidization. The karyotype of the A. sibirica seeds obtained from the Biology Department of Jilin Tonghua Normal University was type 2A, whereas the other four specimens were placed in the type $2 \mathrm{~B}$ category of the Stebbins karyotype classification. This indicates that this $A$. sibirica sample possibly represented the most primitive species among the five specimens 


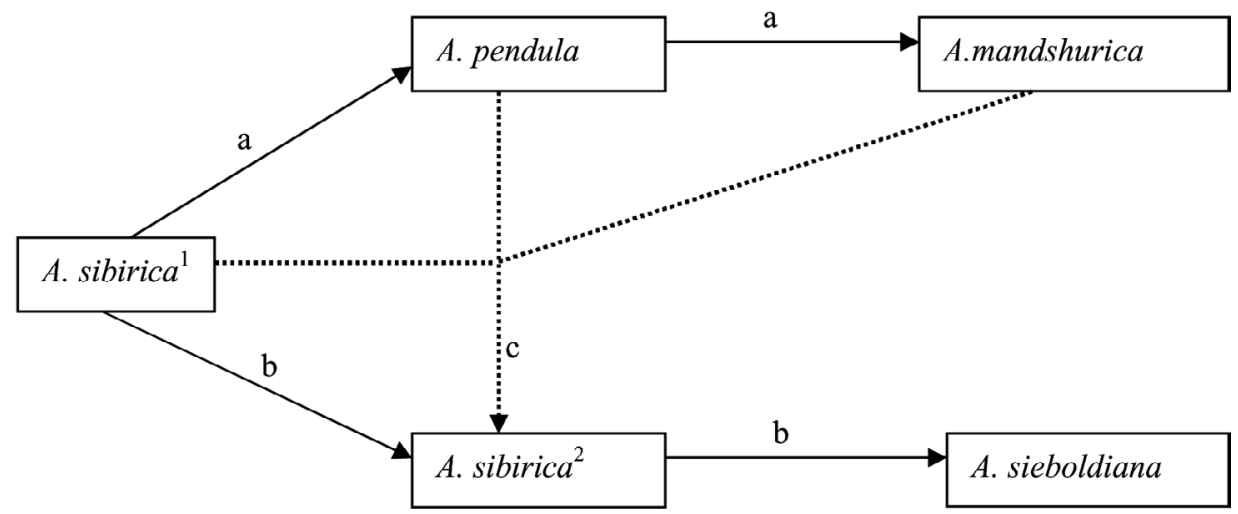

Figure 2. - Assumed evolutionary relationship among the five specimens. a, chromosome evolution; b, chromosome doubling; c, possible natural hybridization; ${ }^{1} 2 \mathrm{n}=28 ;{ }^{2} 2 \mathrm{n}=56$.

and that $A$. pendula was formed by a chromosome karyotype change from such a form to become $A$. mandshurica (Fig. 2). The other evolutionary change was polyploidization. The $A$. sibirica $(2 \mathrm{n}=56)$ specimen from Heilongjiang perhaps evolved from A. sibirica $(2 \mathrm{n}=28)$ by chromosome doubling or from hybridization between tetraploid A. sibirica and tetraploid A. pendula or A. mandshurica, or between $A$. incana and A. glutinosa (BANAEV and BAZANT, 2007). Finally, A. sieboldiana $(2 \mathrm{n}=$ $112)$ evolved from $A$. sieboldiana $(2 \mathrm{n}=56)$ by chromosome doubling. The present results support the previous view that the center of origin of Alnus is Japan (MURAI, 1964; FURLOW, 1979; CHEN and LI, 2004) because species with the most basal chromosome numbers $(2 \mathrm{n}=14)$ were only reported in Japan. In addition, until now, the oldest fossil evidence of Alnus pollen also comes from Japan, reinforcing the hypothesis that Japan was a center of origin of Alnus.

\section{Acknowledgments}

We express our gratitude for the financial support from the National Natural Science Foundation of China (No. 30730065). We also are grateful to Dr. R. A. McInTosh, University of Sydney, Sydney, NSW, Australia, for revising the manuscript.

\section{References}

BANAEV, E.V. and V. BAZANT (2007): Study of natural hybridization between Alnus incana (L.) Moench. and Alnus glutinosa (L.) Gaertn. Journal Forest Science 53: 66-67.

Brunner, I. L., F, Brunner and O. K. JR. Miller (1990): Ectomycorrhizal synthesis with Alaskan Alnus tenuifolia. Canadian Journal of Botany 68: 761-767.

CHEN, Z. D., and J. H. LI (2004): Phylogenetics and biogeography of Alnus (Betulaceae) inferred from sequences of nuclear ribosomal DNA ITS region. International Journal of Plant Science 165: 325-335.

ChiBA S. (1962): Studies on the breeding of Betula and Alnus species. (1) On the differences of morphological characters and chromosome numbers between Alnus hirsuta and Alnus hirsuta var. microphylla. Journal of Japanese Forestry Society 44: 237-243.
DAWson, J. O. (1990): Interactions among actinorhizal and associated plant species. In: SCHWINTZER, C. R., TJEPkemA, J. D., eds. The biology of Frankia and actinorhizal plants. San Diego, California: Academic Press. p 299-316.

FURLOW, J. J. (1979): The systematics of the American species of Alnus (Betulaceae). Rhodora 81: 1-121.

HuZIwARA, Y. (1962): Karyotype analysis in some genera of Compositae. VIII. Further studies on the chromosome of Aster. American Journal of Botany 49: 116-119.

KRSTINIĆ, A. (1994): Genetics of Black Alder (Alnus glutinosa L. Gaertn.), Annales Forestales 19/2:33-72, Zagreb.

KUANG, K. R. (1979): Annals of Chinese Plants. Beijing: Science Press, p (21): 94-103.

Levan, A. K., A. K. Fredga and A. A. Sandberg (1964): Nomenclature for centromeric position on chromosomes. Hereditas 52: 201-220.

Liu, H., G. J. Yan, F. C. Shan and R. Sedgley (2006): Karyotypes in Leucadendron (Proteaceae): Evidence of the primitiveness of the genus. Botany Journal Linnean Society 151: 387-394.

MANDAKOVA, T. and M. A. LYSAK (2008): Chromosomal phylogeny and karyotype evolution in $\mathrm{x}=7$ crucifer species (Brassicaceae). Plant Cell 20: 2559-2570.

MURAI, S. (1964): Phytotaxonomical and geobotanical studies on gen. Alnus in Japan. III. Taxonomy of whole world species and distribution of each sect. Bulletin of the Government Forest Experiment Station, Meguro 171: 1-107.

Probatova, N. S. and A. P. Sokolovskaya (1989): Chromosome numbers in vascular plants from Primorye Territory, the Amur region, Sakhalin, Kamchatka and the Kuril Islands. Botaničeskij Žurnal (Moscow \& Leningrad) 74:120-123.

RAMACHANDRAN, C., R. A. PAI and V. S. SEShadRI (1983): A Feulgen technique for identification of cucumber chromosome. Cellular and Molecular Life Sciences 39: 1155-1156.

ReN, B. Q. and J. LiU (2006): Cytological study on Alnus in China (I). Guihaia 26: 356-359.

Restrepo, G. C. (1994): Gervais Chromosome numbers of some Latin American species of Alnus (Betulaceae). Rhodora 96: 69-74.

Shan, F., G. Yan and J. A. Plummer (2003): Karyotype evolution in the genus Boronia (Rutaceae). Botany Journal Linnea Society 142: 309-320. 
Somego, M. (1976): Chromosome number of in four Alnus species of sect. Bifurcates. Bulletin of the Government Forest Experiment Station Meguro. 287: 77-84.

StarodubtSeV, V. N. (1997): Chromosome numbers in some rare species of vascular plants from the Russian Far East. Botaničeskij Žurnal (Moscow \& Leningrad): 121-122.

Stebbins, G. L. (1971): Chromosomal evolution in higher plants. London: Edward Aronld LTD, 87-93.

Watanabe, K., R. M. King, T. YahaRA, M. Ito, J. YoKoYAMA, T. SUZUKI and D. J. CRAWFord (1995): Chromosomal cytology and evolution in Eupatorieae (Asteraceae). Ann Mis Botany Garden 82: 581-592.
Watanabe, K., T. Yahara, T. Denda and K. Kosuge (1999): Chromosomal evolution in the genus Brachyscome (Asteraceae, Astereae): statistical tests regarding correlation between changes in karyotype and habit using phylogenetic information. Journal Plant Research 112: $145-161$.

ZARCO, C. R. (1986): A new method for estimating karyotype asymmetry. Taxon 35: 526-530.

\title{
Realized Genetic Gains in Coastal Douglas-fir in British Columbia: Implications for Growth and Yield Projections
}

\author{
By M. StoenR ${ }^{1), 4)}$, K. BirD ${ }^{2)}$, G. Nigh ${ }^{1)}$, J. Woods ${ }^{3)}$ and A. YAnchuK ${ }^{1)}$
}

(Received 10 ${ }^{\text {th }}$ November 2009)

\begin{abstract}
Realized genetic gain trials for coastal Douglas-fir (Pseudotsuga menziesii (Mirb.) Franco) at five different sites with four different spacings were assessed at age 12 to compare early gain predictions in growth from small plot progeny test designs to those obtained from large block designs. Seedlings from three genetic levels, i.e., local wild-stand controls (WS), a mid-gain seedlot (MG), and a top-cross seedlot (TC) were planted in $12 \mathrm{x}$ 12 tree plots with two replications at spacings of $1.6 \mathrm{~m}$, $2.3 \mathrm{~m}, 2.9 \mathrm{~m}$ and $4.0 \mathrm{~m}$. Two replications of a "single-tree plot" design at $2.9 \mathrm{~m}$ spacing for the three genetic levels (30 trees per genetic level) were also established, to allow for more detailed comparisons between single-tree

1) Research Branch, British Columbia Ministry of Forests and Range, 727 Fisgard St,.Victoria, BC, V8W 1R8, Canada.

2) Research Branch, British Columbia Ministry of Forests and Range, Cowichan Lake Research Station, 7060 Forestry Road, Mesachie Lake, BC, V0R 2N0, Canada.

$\left.{ }^{3}\right)$ Forest Genetics Council of BC, 3370 Drinkwater Road, Duncan, BC, V9L 5Z2, Canada.

4) Communicating author: Michael Stoenr. Telephone 250-3566269, Fax 250-387-0046. E-Mail: michael.stoehr@gov.bc.ca
\end{abstract}

and multiple-tree plot means. Although these trials are still relatively young, trees in the closest spacing had the highest levels of mortality with the TC trees having the highest rate of survival. Height gains in the block trials ranged from $10.4 \%$ to $16.1 \%$ for MG and TC trees, respectively, and were relatively close to the predicted values; however, volume (individual tree and volume/ha) gains exceeded expectations. Effects of genetic entry on height at age 12 were highly significant, while spacing, genetic entry by spacing, and genetic entry by test site interactions were not significant. We also compared height growth over the first 12 years to growth estimated from the "Bruce height growth model" for Douglas-fir and found that on four of the five test sites our MG and TC seedlings follow the expected height growth trajectories.

Key words: Pseudotsuga menziesii, breeding value, competition, spacing.

\section{Introduction}

The genetic improvement program for coastal Douglas-fir (Pseudotsuga menziesii (Mirb.) Franco) in 